\title{
Monocarboxylate Transporter 1
}

National Cancer Institute

\section{Source}

National Cancer Institute. Monocarboxylate Transporter 1. NCI Thesaurus. Code C107462.

Monocarboxylate transporter 1 (500 aa, 54 kDa) is encoded by the human SLC16A1 gene. This protein is involved in monocarboxylate transport across the plasma membrane. 